\title{
Spectral Analysis of Respiratory Responses to Tracheobronchial and Laryngeal Stimulation in Cats
}

\author{
H. BARÁNI ${ }^{1}$, M. JAVORKA ${ }^{2}$, J. JAKUŠ ${ }^{1}$, I. POLIAČEK ${ }^{1}$, A. STRÁNSKY ${ }^{1}$ \\ ${ }^{1}$ Department of Biophysics, ${ }^{2}$ Department of Physiology, Comenius University, \\ Jessenius Faculty of Medicine, Martin, Slovak Republic \\ Received January 6, 2005 \\ Accepted June 6, 2005
}

\begin{abstract}
Baráni H., M. Javorka, J. Jakuš, I. Poliaček, A. Stránsky: Spectral Analysis of Respiratory Responses to Tracheobronchial and Laryngeal Stimulation in Cats. Acta Vet Brno 2005, 74: 191-198.

The power spectral analysis of the phrenic nerve activity during eupnoeic inspiration and during inspiratory phase of mechanically induced tracheobronchial and laryngeal cough was performed on cats anaesthetized by chloralose or pentobarbital. Distribution of the spectral power was analysed in the four frequency bands: p0-20, p20-40, p40-60, p60-80, which represent frequency range of the corresponding percentage intervals of total spectral power. The computed spectra were compared. The total power of cough inspiratory activity was several times higher, comparing to inspiration during quiet breathing. Cough spectra revealed the higher power at lower frequency range, being demonstrated as a narrower $\mathrm{p} 0-20$, comparing to the quiet breathing. No significant differences were determined in spectral power distribution between tracheobronchial and laryngeal coughs. The effect of anesthesia was manifested by narrower power interval p0-20 for eupnoeic inspiration and p40-60 for both types of cough (inspiratory phase) in cats under chloralose anesthesia, compared to those under pentobarbital anesthesia. Our findings indicate the significant differences in power spectra of phrenic nerve activity during eupnoea and cough.
\end{abstract}

Phrenic nerve activity, quiet breathing, tracheobronchial and laryngeal cough, pentobarbital and chloralose anesthesia

An important feature of the respiratory neural control system is a tight coordination among different respiratory motoneuron populations working together in order to assure an adequate ventilation. During inspiration, the phrenic and external intercostal motoneurons fire to produce inspiratory (I) airflow, whereas motoneurons innervating laryngeal abductors are activated in I phase of breathing in order to widen the laryngeal calibre. The synchrony of these firing activities implies the possible existence of common inputs from the neuronal circuits from breathing central pattern generator to the different respiratory motoneuron pools.

The method of power spectral analysis (Ackerson et al. 1983; Cohen et al. 1987; Baráni et al. 1987; Richardson 1988; Marchenko et al. 2002; St. John and Leiter 2003) was successfully used to study the electrophysiological signals during breathing. Two prominent fast rhythms are generally involved in the phrenic neurogram, being manifested as periodic bursts of the phrenic nerve activity and the peaks in the power spectrum of this activity. These rhythms were named the medium-frequency oscillations (MFOs, with usual frequency range $20-50 \mathrm{~Hz}$ ) and the high-frequency oscillations (HFOs, in frequency range $50-100 \mathrm{~Hz}$ ) (Cohen et al. 1987). The similar rhythms during eupnoea are also detectable in the diaphragmatic muscle activity, as well as in I bursting activities of other nerves (e.g. the recurrent laryngeal or hypoglossal nerves) in cats under a variety of conditions (anaesthesia or decerebration, paralysis and artificial ventilation or spontaneous breathing) (Cohen 1973; Cohen et al. 1987; Richardson and Mitchell 1982; Richardson 1988;

Address for correspondence:

Ing. Helena Baráni, CSc.

Department of Medical Biophysics

Comenius University, Jessenius Faculty of Medicine

Malá Hora 4

03754 Martin, Slovak Republic

Phone + 421-43-4221422

Fax:+ 421-43-4222260

E-mail: barani@jfmed.uniba.sk

http://www.vfu.cz/acta-vet/actavet.htm 
Tomori et al. 1995). Similar findings were obtained in rabbits (Schmidt and Böhmer 1989); or in rats (Ko c sis and Gy imes i-Pelcer 1997). The character of HFOs established in the different nerves was usually identical. In contrast, the MFOs in individual nerves were different, and the correlation among them appeared to be rare and weak (Cohen et al. 1987).

The cough is the most important defensive airway reflex. Cough can be easily evoked in the cat by mechanical stimulation of the rapidly adapting irritant vagal receptors of the tracheobronchial (TB) or laryngopharyngeal mucosa (Korpáš and Tomori 1979). In former studies the central part of cough reflex arc was suggested as an anatomically independent and well circumscribed "cough centre". However, the importance of neurons in several brainstem regions (e.g. medullary raphe region, rostral pons, dorsal and ventral respiratory groups) in formation of the cough reflex were reported just lately (Jakuš et al. 2000; Shannon 1998, 2000). Recording of the neuronal activities in rostral part of the ventral respiratory group revealed, that the discharge pattern of many medullary respiratory neurons involved in quiet breathing (QB) generation is markedly altered also during coughing (Jakuš et al. 1985; S hannon et al.1996; 2000). Thus, it seems that the respiratory central pattern generator may play a substantial role both in generation of quiet breathing and a production the motor program for the cough reflex (Shannon et al. 2000). The efferent discharges of the phrenic nerve are considered as a pertinent indicator for the output from the respiratory or the "cough" central pattern generators. In the present study, we performed the power spectral analysis of the inspiratory phrenic nerve activities in cats during quiet breathing under pentobarbital $\left(\mathrm{QB}_{\mathrm{P}}\right)$ and chloralose $\left(\mathrm{QB}_{\mathrm{CH}}\right)$ anesthesia, tracheobronchial $\left(\mathrm{TBC}_{\mathrm{P}}, \mathrm{TBC}_{\mathrm{CH}}\right)$ and laryngeal $\left(\mathrm{LC}_{\mathrm{P}}, \mathrm{LC}_{\mathrm{CH}}\right)$ cough under both types of anesthesia, respectively.

\section{Materials and Methods}

The experiments were carried out on 8 anaesthetized non-paralyzed adult cats of either sex (mean body weight $3.3 \pm 0.36 \mathrm{~kg}$ ) divided in two experimental groups. The animals were kept in University Animal Care Unit under veterinary care (food and drinking water were supplied ad libitum). The protocol was approved by the Local Medical Ethics Committee. Group 1 (4 cats) consisted of animals under pentobarbital anesthesia (P) (Pentobarbital, Spofa), with an initial intraperitoneal dose $35 \mathrm{mg} \cdot \mathrm{kg}^{-1}$ given intraperitoneally (i.p.), and maintenance doses $1 \mathrm{mg} \cdot \mathrm{kg}^{-1} \cdot \mathrm{h}^{-1}$. Group 2 (4 cats) included cats anaesthetized with $\alpha$-glucosochloralose (CH) (Merck, $50 \mathrm{mg} \cdot \mathrm{kg}^{-1}$ ) given i.p.

\section{Surgical preparation}

The general surgery was the same in both experimental groups. After a midcervical incision the exposed trachea was sectioned below the larynx and its both ends were cannulated. The caudal tube was connected to a pneumotachograph (Commet LBL 50) to record a tracheal airflow. Respiratory rate and end-tidal $\mathrm{CO}_{2}$ were monitored using a capnograph (Capnogard, Novametrix). Polyvinyl catheters were introduced into the right femoral artery for recording of the systemic blood pressure, and into the right femoral vein for administering of anesthetics and solutions. Rectal temperature was maintained stable at $38 \pm 0.5^{\circ} \mathrm{C}$ using a heating pad. TBC and LC were elicited by mechanical stimulation of the TB and laryngeal regions with an elastic nylon fiber (diameter $0.3-0.5 \mathrm{~mm}$ ) through the caudal or distal tracheal tube, respectively. For recording of neural respiratory activity, the right phrenic nerve, composed of cervical roots $\mathrm{C}_{5-6}$, was dissected from the surrounding tissue and cut distally. Fat, connective tissue, and the nerve sheaths were removed.

Data recording

The exposed phrenic nerve was placed on a bipolar silver electrode and immersed in a pool of paraffin oil. The electrodes were connected to low-noise amplifier Iso-DAM8, World Precision Instruments (gain $10^{3}$, bandpass $10 \mathrm{~Hz}, 1 \mathrm{kHz}$ ). The output from the amplifier was fed to differential amplifier Tektronix 5A22N (gain 10, bandpass $10 \mathrm{~Hz}, 1 \mathrm{kHz}$ ). The signal was then sampled at $1 \mathrm{kHz}$ using a 12-bit analog-to-digital converter (National Instruments) and fed by PC (Dell).

Data analysis

Power spectral analysis of the phrenic nerve activities was performed by Fast Fourier transform with the Hanning window to avoid spectral leakage. Due to signal non-stationarity, the analysed window of 256 samples (corresponding to $0.256 \mathrm{~s}$ ) was shifted through the record with the step of 10 samples. Based on the previous findings (Cohen et al. 1987; Richards on 1988), we tried to evaluate stable oscillations in the 20-100 Hz frequency band. However, sustained oscillations in this band were not found so distinct in our signals. Therefore, we decided to describe our power spectra by dividing it into quantiles. This enabled us to quantify some spectral characteristics of 
the signal without requirements for knowing its spectral bands. This method was previously used with advantage on analysis of the cough sound (Jav orka et al.2002). The area under the power spectral density curve - the total spectral power - was computed for each spectrum. The four adjacent spectra around the spectrum with the maximal total power in a given signal were averaged to obtain the representative spectrum for each analysed signal. The frequency of $20^{\text {th }}, 40^{\text {th }}, 60^{\text {th }}, 80^{\text {th }}$ percentiles (P 20, P 40, P 60, P 80) specifies the frequency of the power spectrum under which the corresponding percentage $(20 \%, 40 \%, 60 \%, 80 \%)$ of the total spectral power can be found; e.g. $40 \%$ of the total spectral power lies under the frequency of the P 40. The second band p20-40, p40-60 (third band) and p60-80 (fourth band) are bounded with two frequencies of the corresponding percentiles and therefore the spectral power in each band is equal to $20 \%$ of the total spectral power. The width of the frequency bands (FBs) expressed in $\mathrm{Hz}$ was quantified. The width of the first band p0-20 was defined as $\mathrm{P} 20-0 \mathrm{~Hz}(0 \mathrm{~Hz}$ is equal to the lower end of the spectrum).

\section{Statistical evaluation}

The results are expressed as mean \pm S.E.M. Analysis of variance (ANOVA) and Wilcoxon test were used to determine the significance of the differences, as appropriate. Significance was assumed at $p<0.05$.

\section{Results}

In our experiments the power spectrum analysis of the efferent phrenic nerve activity was performed during eupnoea and the cough reflex. The burst of electrical discharges in the phrenic nerve (PHR) was observed during the inspiratory phase of coughing. Hence, the cough phrenic neurogram was characterized with elevated and prolonged burst of the PHR electrical activity. Corresponding airflow $(\stackrel{\circ}{)})$ during deep initial inspiration of cough was much higher than during the eupnoeic inspiration. Cough inspiratory phase was immediately followed by an expiratory phase (including the compressive phase) manifested by a high expiratory airflow (Fig. 1).

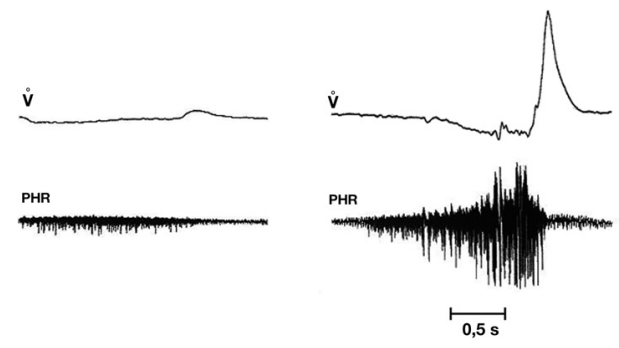

Fig. 1. Records of airflow $\left(V^{\circ}\right)$ and the inspiratory burst of phrenic nerve (PHR) activities during quiet breathing and tracheobronchial cough under chloralose anesthesia

The sequence of power spectra of PHR activity during one $\mathrm{QB}_{\mathrm{CH}}$ and the following $\mathrm{TBC}_{\mathrm{CH}}$ are shown in Fig. 2. Under chloralose anesthesia, the maximal power in $\mathrm{TBC}_{\mathrm{CH}}$ was 5.2-times higher $(p<0.001)$ and in $\mathrm{LC}_{\mathrm{CH}}$ 5.0-times higher $(p<0.001)$ than in $\mathrm{QB}_{\mathrm{CH}}$. Under pentobarbital anesthesia, the maximal power in $\mathrm{TBC}_{\mathrm{P}}$ was 5.8 -times higher $(p<0.001)$ and in LCP 12.1-times higher $(p<0.001)$ than in $\mathrm{QB}_{\mathrm{P}}$.

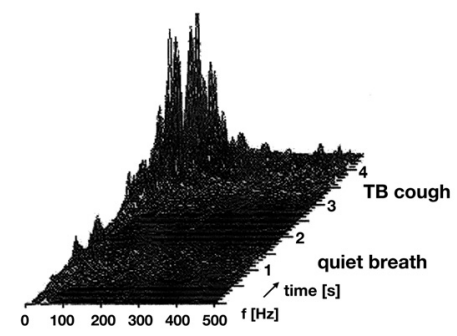

Fig. 2. Power spectra vs. time for phrenic nerve activity during one quiet breath and the inspiratory phase of tracheobronchial (TB) cough in cat under chloralose anesthesia 
The distribution of spectral power in FBs (p0-20, p20-40, p40-60 and p60-80) of PHR activity during eupnoea and during the inspiratory phase of $\mathrm{TBC}_{\mathrm{CH}}$ is presented in Fig. 3 .

quiet breathing

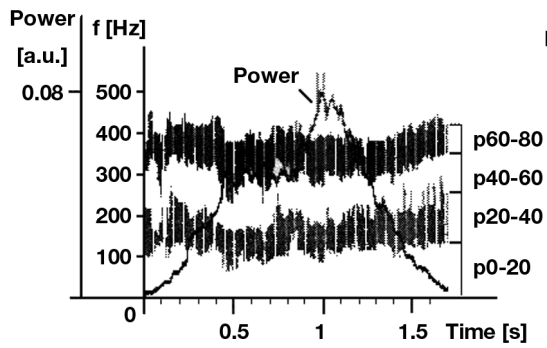

TB cough

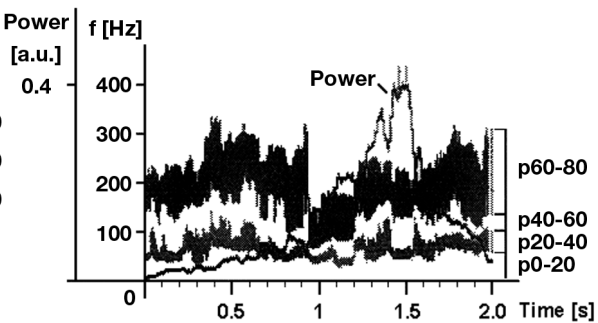

Fig. 3. Distribution of power in frequency bands of phrenic nerve activity during the inspiratory phase of QB and $\mathrm{TBC}$, under chloralose anesthesia. Spectral power curves differ in y-axis scales for better arrangement of graph (a.u.- arbitrary unit)

Comparison of FB widths in coughs and QB (Table 1) under pentobarbital or chloralose anesthesia revealed that widths of $\mathrm{p} 0-20$ during $\mathrm{LC}_{\mathrm{P}}$ and $\mathrm{TBC}_{\mathrm{P}}$ were narrower than $\mathrm{p} 0-20$ in $\mathrm{QB}_{\mathrm{P}}(p<0.001)$. Conversely, p60-80 in both types of cough were wider comparing to p60-80 in $\mathrm{QB}_{\mathrm{P}}(p<0.05)$.

Table 1. The frequency band widths of the coughs (LC, TBC) and quiet breathing (QB) under both types of anesthesia. Significant differences between cough and QB above the values

\begin{tabular}{|c|c|c|c|c|c|c|c|c|c|}
\hline & \multicolumn{4}{|c|}{ PENTOBARBITAL anesthesia } & & \multicolumn{4}{|c|}{ CHLORALOSE anesthesia } \\
\hline & p0-20 & p20-40 & $\mathrm{p} 40-60$ & p60-8 & & p0-20 & p20-40 & $\mathrm{p} 40-60$ & p60-80 \\
\hline & $\mathrm{Hz}$ & $\mathrm{Hz}$ & $\mathrm{Hz}$ & $\mathrm{Hz}$ & & $\mathrm{Hz}$ & $\mathrm{Hz}$ & $\mathrm{Hz}$ & $\mathrm{Hz}$ \\
\hline & $* * *$ & & & * & & $*$ & $* *$ & & $*$ \\
\hline $\mathrm{LC}_{\mathrm{p}}$ & $41 \pm 9$ & $72 \pm 10$ & $96 \pm 6$ & $123 \pm 9$ & $\mathrm{LC}_{\mathrm{CH}}$ & $43 \pm 5$ & $45 \pm 8$ & $74 \pm 7$ & $132 \pm 9$ \\
\hline $\mathrm{QB}_{\mathrm{P}}$ & $102 \pm 7$ & $91 \pm 6$ & $96 \pm 5$ & $99 \pm 5$ & $\mathrm{QB}_{\mathrm{CH}}$ & $62 \pm 6$ & $76 \pm 6$ & $89 \pm 7$ & $107 \pm 4$ \\
\hline & $* * *$ & & & $*$ & & & & & \\
\hline $\mathrm{TBC}_{\mathrm{p}}$ & $41 \pm 9$ & $68 \pm 12$ & $100 \pm 8$ & $120 \pm 8$ & $\mathrm{TBC}_{\mathrm{CH}}$ & $41 \pm 5$ & $49 \pm 7$ & $61 \pm 7$ & $109 \pm 6$ \\
\hline $\mathrm{QB}_{\mathrm{P}}$ & $101 \pm 7$ & $90 \pm 7$ & $93 \pm 5$ & $96 \pm 6$ & $\mathrm{QB}_{\mathrm{CH}}$ & $62 \pm 12$ & $72 \pm 9$ & $71 \pm 8$ & $102 \pm 6$ \\
\hline
\end{tabular}

$* p<0.05, * * p<0.01, * * * p<0.001$

In cats under chloralose anesthesia, p0-20 and p20-40 were narrower in $\mathrm{LC}_{\mathrm{CH}}$ than these FBs in $\mathrm{QB}_{\mathrm{CH}}\left(p<0.05, p<0.01\right.$, respectively). Also $\mathrm{p} 0-20$ of $\mathrm{LC}_{\mathrm{P}}$ was narrower compared to $\mathrm{p} 0-20$ during $\mathrm{QBP}(p<0.001)$. Conversely, p60-80 in $\mathrm{LC}_{\mathrm{CH}}$ and $\mathrm{LC}_{\mathrm{P}}$ were wider than p60-80 during $\mathrm{QB}_{\mathrm{CH}}$ and $\mathrm{QBP}(p<0.05)$. No significant differences were found among the widths of frequency bands for $\mathrm{TBC}_{\mathrm{CH}}$ and $\mathrm{QB}_{\mathrm{CH}}$.

Distribution of power in spectra of $\mathrm{QB}$ under different kinds of anesthesia exposed the following difference: the width of $\mathrm{p} 0-20$ for $\mathrm{QB}_{\mathrm{P}}$ was wider than that for $\mathrm{QB}_{\mathrm{CH}}(p<0.05)$ (Fig. 4).

When we compared FBs in LC or TBC under both types of anesthesia (Fig. 5), we found that $\mathrm{p} 40-60$ of $\mathrm{LC}_{\mathrm{P}}$ was wider than $\mathrm{p} 40-60$ of $\mathrm{LC}_{\mathrm{CH}}(p<0.05)$. Similarly, $\mathrm{p} 40-60$ of $\mathrm{TBC}_{\mathrm{P}}$ was wider than $\mathrm{p} 40-60$ in $\mathrm{TBC}_{\mathrm{CH}}(p<0.001)$. 


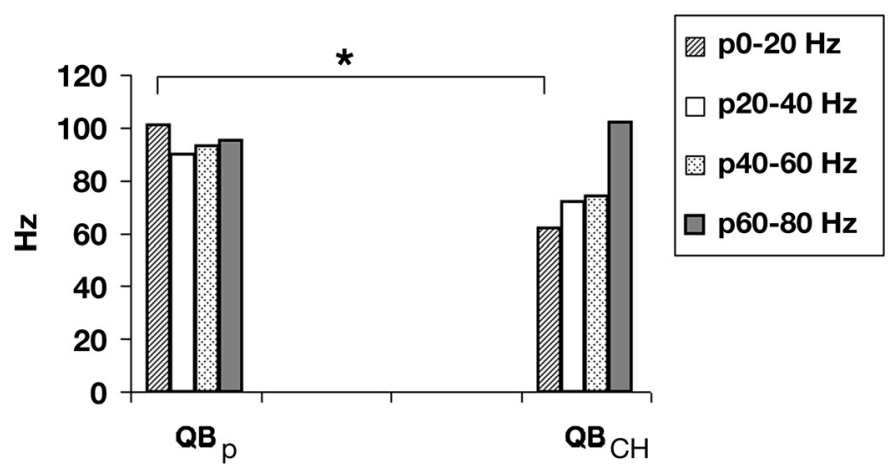

Fig.4. Frequency band widths in laryngopharyngeal and tracheobronchial coughs under chloralose compared to the cough band widths under pentobarbital anesthesia $\left(\mathrm{LC}_{\mathrm{CH}}\right.$ vs. $\left.\mathrm{LC}_{\mathrm{P}}, \mathrm{TBC}_{\mathrm{CH}} \mathrm{vs} \mathrm{TBC}_{\mathrm{P}}\right) * p<0.05, * * * p<0.001$

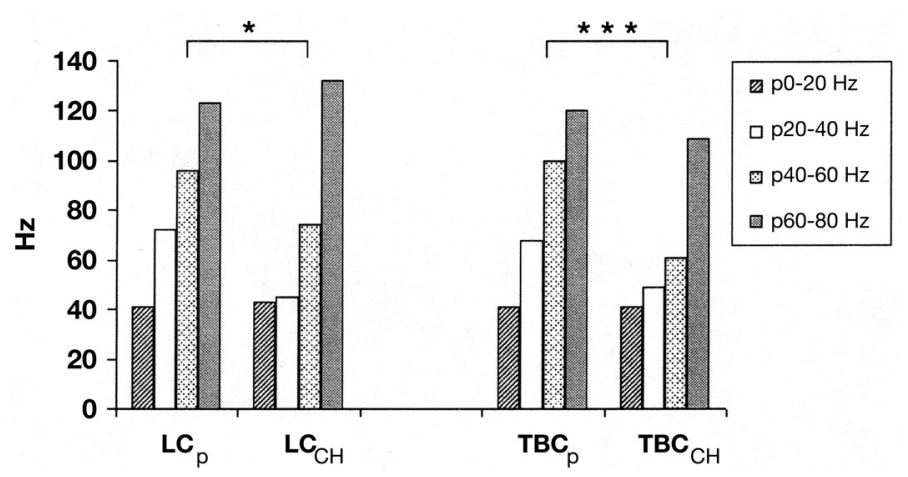

Fig. 5. Frequency band widths in laryngopharyngeal and tracheobronchial cojghs under chloralose compared to the couhg band widths under pentobarbital anesthesia $\left(\mathrm{LC}_{\mathrm{CH}}\right.$ vs. $\mathrm{LC}_{\mathrm{P}}, \mathrm{TPC}_{\mathrm{CH}}$ vs. $\left.\mathrm{TBC}_{\mathrm{P}}\right)$. $* p<0.05, * * *<0.001$

Differences in the spectral power distribution between $\mathrm{LC}_{\mathrm{CH}}$ and $\mathrm{TBC}_{\mathrm{CH}}$ as well as those between $\mathrm{LC}_{\mathrm{P}}$ and $\mathrm{TBC}_{\mathrm{P}}$ were found as no significant.

\section{Discussion}

The purpose of the present study was to perform power the spectral analysis of the inspiratory phrenic nerve activities during $\mathrm{QB}$ and $\mathrm{TBC}$ or LC, and to determine possible differences in their spectra under two types of anesthesia.

As it was assumed before the anesthetics may affect the power spectral densities of the phrenic nerves (Cohen 1973; Richardson and Mitchell 1982; Gootman et al. 1990). In our study, distribution of spectral power was analysed in frequency bands p0-20, p20-40, p4060 and p60-80 (see Materials and Methods). Comparison of band widths and power distribution for $\mathrm{QB}_{\mathrm{P}}$ and $\mathrm{QB}_{\mathrm{CH}}$ revealed, that the spectral power for $\mathrm{QB}_{\mathrm{CH}}$ was more cumulated in the region of low frequencies. This fact is demonstrated by narrower $\mathrm{p} 0-20$ for $\mathrm{QB}_{\mathrm{CH}}$ than for $\mathrm{QB}_{\mathrm{P}}$. On the other hand, the spectral power for $\mathrm{TBC}_{\mathrm{CH}}$ and $\mathrm{LC}_{\mathrm{CH}}$ was concentrated in the regions of low frequencies under both types of anesthesia in cats. However, the width of p40-60 is significantly narrower in cough spectra under the $\mathrm{CH}$ than in those under the $\mathrm{P}$ anesthesia. Thus, an influence of $\mathrm{P}$ and $\mathrm{CH}$ on spectra during cough augmented inspiratory activity seems to be different than the effect on the eupnoeic inspiration. 
According to Richardson and Mitchell (1982), anesthesia may cause changes of spectra of PHR I activity in two ways. First, the anesthesia may excite one and depress another group of neurons and thus can change the spectral characteristics. Second, the anesthesia may act on the neuronal pathways between the primary source of activity and the motoneuronal pool. Thus the synaptic transmission or cell threshold can be affected and the random noise level can rise in comparison to the effective signal in the nerve.

Dripps and Dumke (1943) and Gordh as well as Aström (1955) demonstrated differences between depressant agents. Relative ability to interfere with "chemical" and "neural" inputs was found distinct for different drugs. E.g., barbiturates selectively inhibit the chemical drive of central origin, whereas chloralose caused depression of both inputs.

Our results revealed important differences between power distribution in the spectra of QB and cough. The spectral power was concentrated in interval of low frequencies for both types of cough compared to the QB (narrower p0-20 and wider p60-80 for coughs than p0-20 and p60-80 for QB, respectively). This fact was apparent mostly in cats under the pentobarbital anesthesia. Recently it has been supposed that respiratory - cough central pattern generator can produce both eupnoeic as well as the cough motor pattern (Bongianni et al. 1998; Shannon et al. 1998; Jakuš et al. 2004). However, our findings indicate that increase of power in spectra of cough (corresponding to the augmented inspiration during cough) is not proportional to the power distribution in spectra of QB (power distributions are different).

Interestingly, we did not find any significant difference in distribution of the spectral power between LC and TBC (spectra) under particular type of anesthesia, however under the $\mathrm{P}$ the maximal power of PHR I activity during LC was more than 2 folds higher than during TBC also, there were described some differences between LC and TBC regarding the inspiratory and expiratory phase (Korpáš and Tomori 1979), elicitability (Korpáš and Tomori 1979; Tatár et al. 1994) as well as the sensitivity to antitusive drugs and central control (Bolser and Davenport 2002). Bolser and co-workers (2002) have proposed to explain the gating mechanism in cough as a functional mechanism which regulates the initiation of the cough motor pattern, its time duration, and the strength of its expiratory effort. It is probable, that the laryngeal and tracheobronchial coughs are controlled by two separate functional "gates". Our results indicate that the changes found in our estimated coughs may reflect the different effect of chloralose and pentobarbital on such gating mechanism. However, these findings as well as our previous (Poliaček et al. 2003) and present results are not in contradiction with the idea of common basic central mechanism (Korpáš 1972; Ivančo 1973; Shannon et al. 1998; Bolser and Davenport 2002). Power spectral analysis of inspiratory phrenic activity during eupnoea and cough revealed significant differences in power distribution during these two behaviors. Our study also confirmed the former findings that anesthesia may strongly and substantially affect the power spectra.

\section{Výkonová spektrálna analýza respiračných odoziev na tracheobronchiálnu a laryngeálnu stimuláciu u anestézovaných mačiek}

Pomocou výkonového spektra aktivity n. frenicus autori analyzovali počas eupnoického inspíria a počas inspiračnej fázy mechanicky vyvolaného tracheobronchiálneho a laryngeálneho kašla u mačiek v pentobarbitalovej a chloralózovej anestéze rozloženie spektrálneho výkonu v štyroch frekvenčných pásmach: p0-20, p20-40, p40-60, p60-80. Tieto pásma predstavujú frekvenčné rozsahy odpovedajúce percentuálnym intervalom celkového spektrálneho výkonu. Získané spektrá vzájomne porovnali. Celkový výkon inspiračnej aktivity kašla bol niekolkonásobne väčší v porovnaní s pokojným inspíriom počas dýchania. Spektrá kašla odhalujú väčší výkon v rozsahu nižších frekvencií, čo je 
prezentované užšou šírkou p0-20 v porovnaní s pokojným dýchaním. Vo výkonovom spektre neboli zistené žiadne signifikantné rozdiely $\mathrm{v}$ inspiračných fázach medzi tracheobronchiálnym a laryngeálnym kašlom. Vplyv anestézie sa prejavil kratším intervalom p0-20 pre eupnoické inspírium a p40-60 pre oba typy kašla (inspiračná fáza) u mačiek pri chloralózovej anestéze v porovnaní s pentobarbitalovou anestézou. Tieto nálezy odhalujú významné rozdiely vo výkonových spektrách pokojného eupnoe a v inspiračných fázach oboch typov kašla.

\section{Acknowledgement}

This study was supported by grant No. 1/2274/05 (VEGA) of the Grant Agency for Science of the Slovak Republic.

\section{References}

ACKERSON LM, BRUCE EN 1983: Bilaterally synchronized oscillations in human diaphragm and intercostals EMGs during spontaneous breathing. Brain Res 271: 346-348

BARÁNI H, TOMORI Z, KULÍŠEK V 1987: Spectral analysis of respiratory parameters in defensive respiratory reflexes. Acta Physiol Hung 70: 255-261

BOLSER DC, DAVENPORT PW 2002: Functional organization of the central cough generation mechanism. Pulm Pharmacol Ther 15: 221-225

BONGIANNI F, MUTOLO D, FONTANA GA, PANTALEO T 1998: Discharge patterns of Bötzinger complex neurons during cough in the cat. Am J Physiol 274: 1015-1024

COHEN MI 1973: Synchronization of discharge, spontaneous and evoked, between inspiratory neurons. Acta Neurobiol Exp 33:189-218

COHEN MI, SEE WR, CHRISTAKOS CN, SICA AL 1987: High-frequency and medium-frequency components of different inspiratory nerve discharges and their modification by various inputs. Brain Res 417: 148-152

DRIPPS RD, DUMKE PR 1943: The effect of narcotics on the balance between central and chemoreceptor control of respiration. J Pharmacol Exp Ther 77: 290-306

GOOTMAN PM, COHEN HL, STEELE AM, SICA AL, CONDEMI G, GANDHI MR, EBERLE LP 1990: Effects of anesthesia on efferent phrenic activity in neonatal swine. Brain Res 522: 131-134

GORDH T, ASTRÖM A 1955: Respiratory effects of oxygen deficiency and carbon dioxide excess during ether and barbiturate anesthesia in the dog. Anesthesiology 16: 245-253

IVANČO I 1973: Functional-morphological organization of respiratory and cough centres. Studia Pneumol Phtiseol Cechoslov 33: 153-156 (in Slovak)

JAKUŠ J, STRÁNSKY A, POLIAČEK I, BARÁNI H, BOŠELOVÁ L' 2000: Kainic acid lesion to the Lateral tegmental field of medulla. Effects on Cough, Expiration and Aspiration reflexes in anesthetized cats. Physiol Res 49: 387-398

JAKUŠ J, TOMORI Z, STRÁNSKY A 1985: Activity of bulbar respiratory neurons during cough and other respiratory tract reflexes in cats. Physiol Bohemoslov 34: 127-136

JAKUŠ J, TOMORI Z, STRÁNSKY A 2004: Neuronal determinants of breathing, coughing and related motor behaviors. Wist, Martin, $335 \mathrm{p}$.

JAVORKA M, JAVORKOVÁ N 2002: Spectral analysis of the cough sound - new method. XVIII. Martin Days of Respiration, pp.14-15

KORPÁS J 1972: The expiration reflex from vocal cords. Physiol Bohemoslov 21: $408-409$

KORPÁŠ J, TOMORI Z 1979: Cough and Other Respiratory Reflexes. Karger, Basel, 356 p.

KOCSIS B, GYIMESI-PELCER K 1997: Power spectral analysis of inspiratory nerve activity in the anesthetized rat: uncorrelated fast oscillations in different inspiratory nerves. Brain Res 745: 309-312

MARCHENKO V, GRANATA AR, COHEN MI 2002: Respiratory cycle timing and fast inspiratory rhythms in the adult decerebrate rat. Am J Physiol-Reg I 283: R931-R940

POLIAČEK I, STRÁNSKY A, JAKUŠ J, BARÁNI H, TOMORI Z, HALAŠOVÁ E, 2003: Activity of laryngeal abductor and adductor muscles during cough, expiration and aspiration reflexes in cats. Physiol Res 52: 749-762

RICHARDSON CA 1988: Power spectra of inspiratory nerve activity with lung inflations in cats. J Appl Physiol 64: $1709-1720$

RICHARDSON CA, MITCHELL RA, 1982: Power spectral analysis of inspiratory nerve activity in the decerebrate cat. Brain Res 233: 317-336

SCHMID, K, BÖHMER, G 1989: Spectral composition of synchronized discharge of phrenic nerve activity in rabbit and effects of pulmonary afferents. Respir Physiol 76: 37-52

SHANNON R, BAEKEY DM, MORRIS KF, LINDSEY BG 1996: Brainstem respiratory networks and cough. Pulm Pharmacol 9: 343-347

SHANNON R, BAEKEY DM, MORRIS KF, LINDSEY BG 1998: Ventrolateral medullary respiratory network and a model of cough motor pattern generation. J Appl Physiol 84: 2020-2035 
SHANNON R, BAEKEY DM, MORRIS KF, LI Z, LINDSEY BG 2000: Functional connectivity among ventrolateral medullary respiratory neurones and responses during fictive cough in the cat. J Physiol 525: 207224

ST.-JOHN WM, LEITER JC 2003: High-frequency oscillations of phrenic activity in eupnea and gasping of in situ rat: influence of temperature. Am J Physiol-Reg I 285: R404-R412

TATÁR M, SANT'AMBROGIO G, SANT'AMBROGIO FB 1994: Laryngeal and tracheobronchial cough in anesthetized dogs. J Appl Physiol 76: 2672-2679

TOMORI Z, FUNG ML, DONIČ V, DONIČOVA V, ST JOHN WM 1995: Power spectral analysis of respiratory responses to pharyngeal stimulation in cats: comparisons with eupnoea and gasping. J Appl Physiol 485: 551-559 